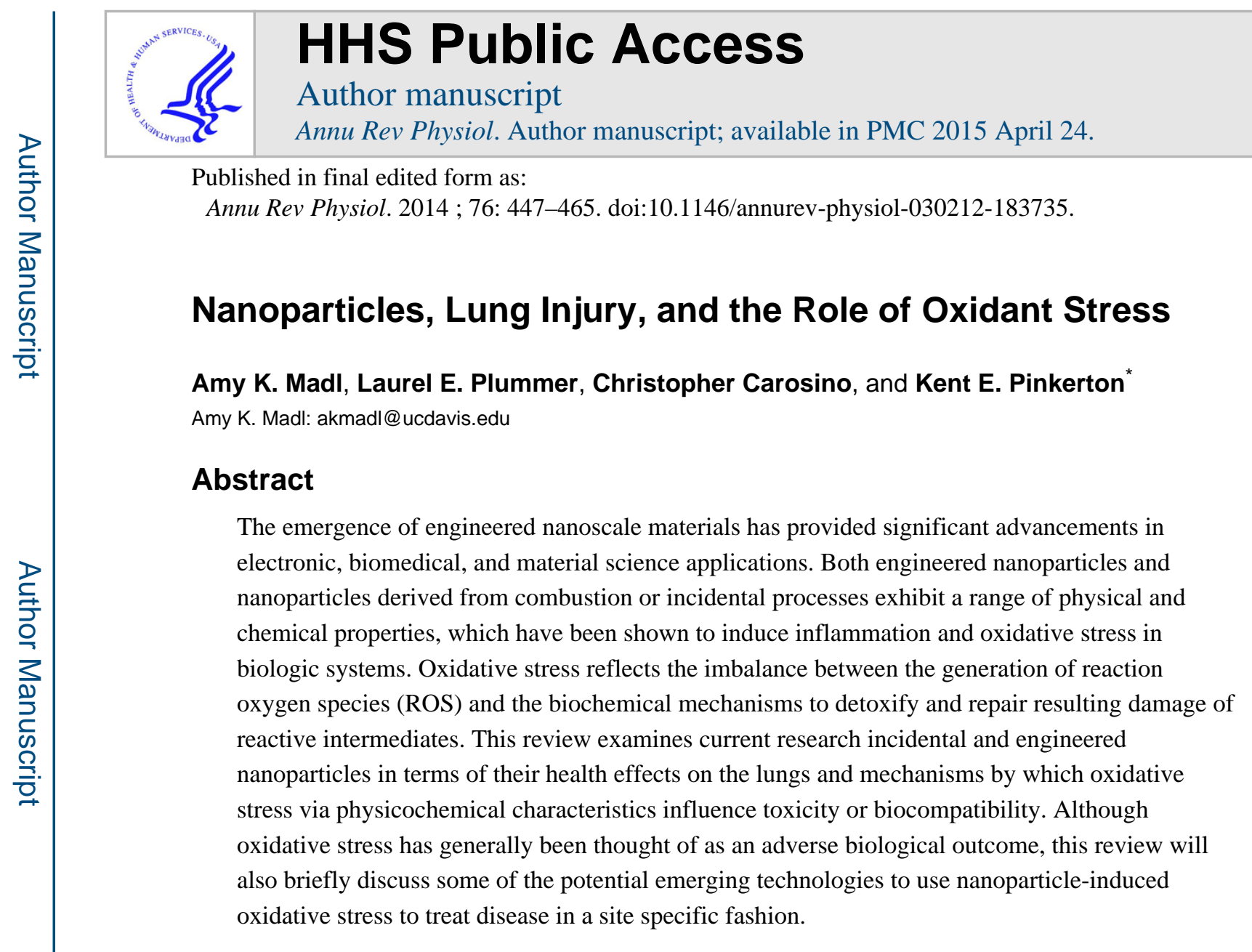

Keywords

Oxidative stress; nanoparticles; carbon nanotubes; ambient particulate matter; lung

\title{
INTRODUCTION
}

The emergence of engineered nanoscale materials has shown promise for significant advancements in the fields of imaging, electronics, and therapeutics (1-7). Although nanotechnology may be an emerging field, the study of particles less than $100 \mathrm{~nm}$ in diameter (also known as ultrafine particles), has been ongoing for decades. Nanoparticles come from many different sources; they exist naturally in the environment (forest fires, viruses, volcanoes), are produced as byproducts of industrial or combustion processes (engines, power plants, incinerators), and are intentionally made for various industrial or consumer product applications (pigments, chemical catalysts). The emergence of nanotechnology has added a new type nanoparticle to this list, specifically engineered nanoparticles. Nanotechnology has been defined as a field that "involves a wide range of technologies that measure, manipulate, or incorporate materials and/or features with at least one dimension between approximately 1 and 100 nanometers $(\mathrm{nm})$. Such applications

\footnotetext{
"Corresponding Author: Center for Health and the Environment, University of California, Davis, One Shields Avenue, Davis, California 95616, (707) 694-9250 phone (Madl), (530) 752-8334 phone (Pinkerton), (530) 752-5300 fax, kepinkerton@ ucdavis.edu. "Posted with permission from the Annual Review of Physiology, 2014, Volume 7 () 447-465 by Annual Reviews, http:// www.annualreviews.org".
} 
exploit the properties, distinct from bulk/macroscopic systems, of nanoscale components" (8).

Engineered nanomaterials being developed today are produced in a variety of compositions (metal, elemental semiconductor, compound semiconductor, metal oxide), shapes (spiral, wire, belt, spring, pillar, helix, etc.), and structures (core/shell, single composition). Similarly, nanoparticles derived from combustion or incidental processes exhibit a range of physical and chemical properties. Incidental nanoparticles generated from combustion processes have the potential for aggregation forming accumulation mode particles with very unique physical and chemical characteristics (9-11). While transition metals and polycyclic aromatic hydrocarbons (PAHs) are primary components of these ambient particles, both engineered and incidental nanoparticles can be high in carbon and metal content. Research has shown relationships between these different physicochemical characteristics of nanoparticles and the induction of inflammation and oxidative stress in biologic systems.

Oxidative stress reflects the imbalance between the generation of reaction oxygen species (ROS) and the biochemical mechanisms to detoxify and repair resulting damage of reactive intermediates. The imbalances in the cellular oxidative state can lead to generation of peroxides and free radicals, which in turn can damage proteins, lipids and DNA. Because ROS act as cellular messengers in redox signaling, oxidative stress can lead to interferences in normal cell signaling. Due to the belief that oxidative stress plays an important role in several neurodegenerative and cardiovascular diseases and is likely involved with the development of age-related cancer, a significant amount of research has been invested over the last several decades to better understand the pathophysiological effects of oxidative stress and the implications for the natural history of disease processes.

The purpose of this review is to examine the role of oxidative stress on the health effects of nanoparticles on the lung. Current research of well-studied nanoparticles, such as ambient ultrafine particles, as well as emerging engineered nanomaterials, such as carbon nanotubes, will be evaluated in terms of their health effects on the lungs and mechanisms by which oxidative stress via physicochemical characteristics influence toxicity or biocompatibility of nanoparticles. Readers are directed to recent reviews on studies and methods to measure oxidative stress from exposure to nanoparticles and proposed screening approaches to predict nanoparticle toxicity or biocompatibility $(12,13)$. Although oxidative stress has generally been thought of as an adverse biological outcome, this review will also briefly touch on some of the potential emerging technologies to use nanoparticle-induced oxidative stress to treat disease in a site specific fashion (e.g., Alzheimer's disease).

\section{MECHANISMS OF OXIDATIVE STRESS}

Nanoparticle-induced oxidative stress is thought to occur through a number of different mechanisms as a result of intrinsic properties of nanoparticles, as well as through extrinsic nanoparticle-cellular interactions (Figure 1). Nanoparticles themselves can have oxidantgenerating properties. Transition metals, which can be major or trace contaminants of incidental or engineered nanoparticles, can catalyze the production of hydroxyl radical from hydrogen peroxide via Fenton-like reactions, which in turn can initiate lipid peroxidation. 
Stable free radical intermediates present on reactive particle surfaces (such as that seen with quartz) and redox active groups (e.g., quinones) on functionalized nanoparticles can be a source of intrinsic particle oxidant sources (14-18). Cells, such as macrophages and neutrophils, can act as potent generators of ROS in response to their interactions with nanoparticles. Mitochondria are the major source of ROS through normal mechanisms of cellular respiration; however, if imbalances occur between oxidant generation and expression of antioxidant enzymes and proteins, oxidant stress can ensue. Recent studies have also suggested that ROS-producing mitochondria can prompt inflammasome activation of phagocytic cells, thus providing the cell signaling link between mitochondria and inflammation $(16,19)$. Ultimately, whether ROS originate from the particles themselves and/or through the cellular response to nanoparticles, oxidative stress and accumulation of oxidative products can lead cell damage and death when the equilibrium between pro- and antioxidants is disrupted.

Endogenous sources of ROS are generated by many cellular and enzymatic players. A primary source of ROS is the generation of a wide variety of oxidants through phagocytic respiratory bursts of macrophages and neutrophils. Much of the understanding of cellular based synthesis of ROS was developed through investigation of antimicrobial systems used by leukocytes in which bacterial killing is facilitated by the generation of a variety of highly effective bactericidal agents, including superoxide anion, hydrogen peroxide, and halooxygen species such as $\mathrm{HOCl}$. The respiratory burst is a metabolic event in which cells manufacture large quantities of highly reactive oxidants in response to a stimulus and is a cyanide insensitive rapid utilization of oxygen and glucose. Leukocytes, such as neutrophils and macrophages, produce ROS during phagocytosis or stimulation with a wide variety of agents through activation of nicotinamide adenine dinucleotide phosphate reduced (NADPH) oxidase (20). The capacity for this rapid response is regulated by protein phosphorylation of key subunit, $\mathrm{p} 47^{\text {phox }}$, a $45 \mathrm{kDa}$ oxidase component that is extensively phosphorylated when the oxidase is activated. This subunit moves to the phagosomal membrane where, as it organizes with the remaining components of the active enzyme, it generates electrons to reduce molecular oxygen (21). The organized oxidase complex acts through a catalytic subunit (gp91 ${ }^{\text {phox }}$, also known as NOX2) to bind NADPH, extract electrons, and transport them across the phagosomal membrane to react with oxygen through an iron-heme complex, thus secreting superoxide into the lumen (22). Differentiated macrophages (such as alveolar macrophages: AM) also generate ROS using NOX2 based metabolism but lack the myeloperoxidase (MPO) present in neutrophils that is necessary for $\mathrm{HOCl}$ generation. Macrophages also generate nitrogen-based radicals through NO synthase and its interaction with active oxygen species. It is now becoming clear that non-phagocytic cells use similar reactive oxygen generating enzyme complexes for both innate defense and intracellular signaling (23).

The balance between the pathological or protective mechanisms of ROS is most apparent in the normal biochemical machinery of the mitochondria. Mitochondria are major producers of ROS and also may be major targets for oxidative damage. This delicate balance between ROS generation in meeting cellular energy demands versus perturbations that lead to dysfunction, cell death, and disease has been a major area of research to better understand 
the fundamental attributes of mitochondria and the role of mitochondrial dysfunction in generating disease $(24,25)$.

Cellular pathogenesis can be initiated and enhanced by mitochondrial oxidative stress. Mitochondrial ROS is generated in the respiratory chain during ATP synthesis due to leakage of electrons from mitochondrial complexes I, II, and III (26). While basal levels of ROS are maintained by cellular and mitochondrial antioxidants, perturbations can lead to mitochondrial oxidative stress, which in turn can result in interruption of the energy supply, calcium imbalances, release of lethal proteins, and a culmination of changes that lead to apoptosis or necrosis. While severe mitochondrial oxidative stress can produce pathological dysfunction that leads to apoptosis or necrosis, minor ROS generation is thought to create a protective "preconditioning" against a subsequent "severe" oxidative stress attack (26).

A hierarchical oxidative stress model has been proposed as a possible explanation of the differential effects of "minor" versus "severe" oxidative stress. In this hierarchical oxidative stress model, "minor" oxidative stress triggers antioxidant protection, whereas "higher" oxidant stress initiates specific signaling and gene expression pathways that can cause cellular and organelle injury and cell death (27-29). Oxidative stress is an imbalance or disequilibrium of the redox state of a cell with cellular glutathione (GSH) and glutathione disulfide (GSSG) being primary regulators of the redox balance. The extent and rate by which GSH/GSSG levels are changed can determine whether stress responses are protective or injurious in nature (30-32). Figure 2 illustrates the careful balance between antioxidant and prooxidant mechanisms and the implications for maintaining biochemical homeostasis or leading to oxidant disruption that translates into cellular toxicity. In the hierarchical oxidative stress model, antioxidant defense, inflammation, and toxicity are defined as the three tiers along the continuum of adaption and compensation of oxidant stresses to an imbalance whereby the protective antioxidant mechanisms breakdown or are overwhelmed. In the first tier, protective antioxidant and detoxifying enzymes are induced. Heme oxygenase (HO-1), glutathione-S-transferase (GST), NADPH quinine oxidoreductase, catalase, superoxide dismutase (SOD), and glutathione peroxidase are examples of enzymes that influence and regulate cellular oxidant capacity $(31,33-36)$. In the second tier of the oxidant stress paradigm, proinflammatory processes are initiated when ROS production surpasses the antioxidant protective mechanisms. These proinflammatory effects are mediated by redox-sensitive MAP kinase and NF- $\kappa$ B cascades, which initiate the expression of cytokines, chemokines and adhesion molecules involved with the inflammatory process in the lungs $(28,30-33)$. In the third tier of the oxidant stress model, cytotoxicity involving perturbation of mitochondrial permeability and electron transfer in organelle respiration results in cellular apoptosis or necrosis $(31,32,37)$.

While it has been well understood that the generation of ROS plays an important role in the pathogenesis of highly surface reactive particles like quartz and asbestos (38-41), it was not until research on nanosized and fine sized low-toxicity, low-solubility particles (i.e., titanium dioxide, carbon black and polystyrene beads) that particle size was also appreciated as an important factor in the role of ROS-mediated cytotoxicity (42-48). For example, exposure to polystyrene nanoparticles, which are thought to be relatively inert because they do not spontaneously produce ROS, resulted in lysosomal leakage, ROS production and 
mitochondrial damage that led to apoptosis in murine macrophages $(29,31)$. This work clearly showed that nanoparticles lacking surface chemical reactivity are still capable of inducing ROS through biological interactions that directly or indirectly target the mitochondria. Since the early studies of low-toxicity, low-solubility particles, researchers have sought to better understand the role and mechanisms by which oxidative stress is generated, biochemical processes are disrupted, and cellular damage is induced from incidental and engineered nanosized particles. The subsequent sections of this chapter address pulmonary health effects resulting from exposure to incidental ambient nanoparticles and engineered carbon nanotubes and what is currently understood in regards to the involvement of oxidative stress in the pathology associated with these two types of nanoparticles.

\section{INCIDENTAL NANOPARTICLES}

\section{Health Effects and Lung Injury}

Particulate air pollutants are complex mixtures derived from a variety of anthropogenic and natural sources. Ambient particulate matter (PM) can cause effects on the respiratory system that are similar to particulates found in occupational settings; however, extrapulmonary changes (e.g., cardiovascular effects) have also been documented from peak exposures to ambient PM. While research of the effects of ambient PM over the last few decades have focused on the PM in the coarse- and fine-sized fractions, considerable efforts have recently been spent understanding the role that ultrafine particles may play in either contributing or exacerbating cardiopulmonary disease in normal and susceptible populations. It should be noted, however, particularly in the era of nanotechnology, that researchers are now referring to ambient ultrafine particles as "nanosized particles produced by incidental means" to make the distinction from engineered nanoparticles.

Dissimilar size fractions of ambient PM have very different physicochemical characteristics, partly because of their emission sources. Coarse particles are generally comprised of natural materials (i.e., minerals, silicates, pollen) derived from weathering and disturbance of earth soils, whereas fine particles usually originate from anthropogenic sources (i.e., combustion processes, industrial emissions) and are comprised of a mixture of elemental and organic carbon, sulfate, nitrate, minerals, and metals. Ultrafine PM is also generated through combustion processes, but can quickly aggregate to form larger sized particles (9-11).

Episodes of intense particulate air pollution have been known to cause increased morbidity and mortality for at least a half-century. The Donora death fog in 1948 and the London fog in 1952 were notable air pollution events that led to upwards of a few thousand excess deaths and, more recently, the work from the Harvard six cities studies in 1993 showed that peak particulate air pollution events led to increased deaths from lung cancer and cardiopulmonary disease (49). Over the last decade, over 100 studies of more than 35 different cities have investigated the acute effects of ambient PM showing increased hospital admissions and deaths from cardiopulmonary disease (e.g., asthma, chronic obstructive pulmonary disease, arrhythmia, heart attack) (50-52). The effects appear to best correlate with $\mathrm{PM}_{2.5}$ with an increased mortality of 0.5 to $1.5 \%$ for every incremental concentration 
increase of $5 \mu \mathrm{g} / \mathrm{m}^{3}$ (51). These studies have served as a basis for the National Ambient Air Quality Standard for PM (10).

There is considerably less information about the chronic effects of ambient particulate pollution. Although lung tissue remodeling is known to occur from exposure to ambient PM, these changes tend to be less prevalent and severe compared to that observed in occupational settings. Autopsy studies have provided some means for assessing the potential long-term effects of exposure to ambient PM. Findings from these studies have suggested that longterm exposures to ambient PM can lead to remodeling of the lungs with the most significant changes occurring in the respiratory bronchioles and bronchoalveolar duct junctions or centriacinar regions of the lungs. Pinkerton et al. (2000), for example, evaluated lungs of deceased young males in California's Central Valley who died of non-respiratory causes. The individuals had been exposed to ambient conditions consisting primarily of mineral and carbonaceous dusts. Dust deposition was principally observed in tissue sections at the terminal bronchioles and first-generation respiratory bronchioles, with less deposition observed in the upper airways (Figure 3). There was significant wall thickening via inflammatory cell accumulation (dust laden macrophages), increased collagen deposition, and smooth muscle cell hypertrophy, resulting in terminal and first-generation respiratory bronchiole structural remodeling. Changes in lung structure and retention of particles appeared to be inversely proportional to the distance from the center of the lung acinus; particle retention decreased from the first-generation, to second-generation, to thirdgeneration of respiratory bronchioles (Figure 4). The effects seen in the respiratory bronchioles were also observed in the lungs of both smokers and non-smokers, with more severe changes occurring in smokers. It was suggested that there might be synergistic effects between ambient PM and cigarette smoke, but despite any interactions, respiratory bronchiole remodeling as a result of exposure to ambient PM could be detected irrespective of the smoking status (53).

The findings from Pinkerton and colleagues have also been observed in other PM exposed populations. Subjects living in high-PM areas in Canada showed increased particle deposition in the respiratory bronchioles and at airway bifurcations that correlated with airway remodeling $(54,55)$. These studies have shown correlations of high ambient PM exposure to particle deposition and airway remodeling in the lungs with indications that fine $\left(\triangle \mathrm{PM}_{2.5}\right)$ and aggregations of ultrafine particles $\left(\mathrm{PM}_{0.1}\right)$ are likely the particle size fraction contributing to these effects because of their prevalence in lung tissue digests $(53,56)$. Further studies comparing individuals exposed to non-occupational, high ambient PM have indicated that ultrafine particles retained in the bronchiole airway walls are associated with fibrogenic small airway remodeling and may produce a chronic airflow obstruction (57). Although these results may suggest possible effects from long-term exposures to ambient particulate air pollution, it is important to keep in mind that other confounders (e.g., genetic, lifestyle, smoking, occupational exposures, other ambient pollutants) may have some contribution to these effects and may not be fully accounted for in the individual case history $(53,55-59)$.

As a means to understand the potential chronic effects of ambient PM, researchers have utilized tracheal explants as a model system for controlling the administered PM dose to a 
particular region of the lungs. More specifically, it has been shown that particles (collected ambient PM, mineral dusts, and diesel exhaust PM) administered into the airway leads to expression of mediators promoting fibrosis and smooth muscle hyperplasia. The expression occurs without exogenous inflammatory cells, and suggests PM may directly cause epithelial cell injury, airway remodeling, and possible obstruction even in the absence of inflammation $(60,61)$. Further, studies of concentrated ambient particles (CAPs) have shown both pulmonary and extrapulmonary effects, including up-regulation of proinflammatory genes and markers of oxidative stress in the lungs, as well as systemic effects suggesting an increased risk of arthrosclerosis $(59,62,63)$.

\section{Role of Oxidative Stress}

Oxidative stress has been identified as one of the primary mechanisms by which ambient particulate air pollution exerts adverse health effects. Of the varying sizes of ambient PM, nanosized particles are thought to be potentially the most hazardous due to the their small size, large surface area, and high relative content of redox-cycling organic chemicals with the ability to penetrate, deposit, and be retained in the deep lung $(28,31)$. Many of the components of nanosized ambient PM, such as metals and organic carbon compounds, are capable of ROS generation through Fenton and Haber Weiss chemistry, as well as redox cycling of organic chemicals (i.e., quinones), which form superoxide radicals (30, 31). The ability of ultrafine particles $\left(\mathrm{PM}_{0.1}\right)$ to generate more free radicals than coarse $\left(\mathrm{PM}_{10}\right)$ and fine particles $\left(\mathrm{PM}_{2.5}\right)$, as measured by induction of heme oxygenase and depletion of intracellular glutathione, may be due to ultrafine particles having a large surface area for adsorption of ROS-generating components (64). Inherent ROS generation is commonly associated with transition metals, such as iron $(\mathrm{Fe})$, copper $(\mathrm{Cu})$, nickel $(\mathrm{Ni})$, cobalt $(\mathrm{Co})$, and vanadium $(\mathrm{V})$. These metals are associated with anthropomorphic sources, with $\mathrm{Fe}$ having an order of magnitude greater concentration in most samples from polluted regions (65). Transition metals such as Fe catalyze the production of hydroxyl radical from hydrogen peroxide via Fenton-like reactions that are enhanced in the presence of physiological concentrations of ascorbate (Figure 1) (66). Using metal chelators or antioxidants to ameliorate the oxidative stress induced by PM have shown that metals play an important role in the pro-oxidant and proinflammatory effects of ambient PM $(31,67)$.

In addition to transition metals, environmental PM contains PAHs and quinones and that undergo redox cycling to generate ROS. In the burning of hydrocarbons, radicals formed early in combustion interact, forming PAHs, including carcinogens, from less complex structures. PAHs will aggregate into nanoparticles, which can extend into branched-chain structures observed as black smoke or soot (68). Quinones are derived from PAH components and likely include such compounds as 1,4-naphthoquinone; 5,12naphthacenequinone; bez $[a]$ anthracene-7,12-dione; and anthracene-9,10-dione. These quinones undergo cyclic reduction reactions with oxygen followed by oxidative coupling with either NADPH or iron to form semiquinones leading to the formation of superoxide radicals (69). Quinones are not only by-products of fuel combustion, but also are generated by the enzymatic conversion of PAH in the lungs $(31,70,71)$. 
The toxic potential of PM in ambient air or from combustion processes has been shown to correlate with the chemical composition and the capacity to induce oxidative stress $(31,72$, 73). Studies of concentrated ambient particles (CAPs) show that nanosized particles, which contain a significant amount of PAHs and quinones, have a greater potency to induce oxidative stress in macrophages and epithelial cells than coarse PM, which is mostly comprised of crustal elements $(31,72)$. Similarly, quinones and PAHs in diesel exhaust particles have been shown to contribute to oxidant injury of the lung $(31,74-76)$. It has also been suggested that oxidative stress generated from organic chemicals on the surface of combustion particles are responsible for not only proinflammatory effects, but also adjuvant effects in the respiratory tract, which can lead to nonspecific and allergic inflammatory processes $(31,73)$. Interestingly, pretreatment of SOD or nitric oxide synthase inhibitors significantly diminished inflammatory cell infiltration, mucus and nitric oxide production, and increased airway hyperreactivity (effects involved in the pathogenesis of asthma), emphasizing the role of oxidant stress on inflammatory processes and pathological outcomes (31,77-79). Similarly, thiol-antioxidants (i.e., N-acetyl-cysteine) suppressed adjuvant effects of diesel exhaust particles on ovalbumin induced allergic responses $(31,80)$. The importance of the role of antioxidant and enzyme detoxification pathways has been further emphasized by the observation of increased nasal allergic and allergen-specific IgE responses in individuals who exhibit GST M1-null genotype following exposure to diesel exhaust particle $(31,81)$. In conclusion, while recent research has provided a better understanding of the potential drivers of oxidative stress from ambient PM, the complexity of particle-cellular interactions and the associated intrinsic and extrinsic sources of ROS still leaves much to be evaluated in terms of defining the role and molecular pathways by which oxidative stress leads to PM induced disease processes.

\section{ENGINEERED NANOMATERIALS}

\section{Health Effects and Lung Injury}

Although nanoscale particles ( $<100 \mathrm{~nm}$ diameter) resulting from manufacturing (i.e., ultrafine titanium dioxide $\left[\mathrm{TiO}_{2}\right]$ or carbon black) or combustion processes (i.e., vehicle exhaust, air pollution) have been studied extensively for decades, the potential biocompatibility and toxicity of engineered nanomaterials have only recently received attention from the scientific community. Carbon-based engineered nanoparticles, such as single-walled carbon nanotubes (SWCNTs), multi-walled carbon nanotubes (MWCNTs), and fullerenes, have received notable attention due to their superior electronic, optical, mechanical, chemical, and even biological properties. Questions have been raised as to whether the unique properties of these materials may exert biological effects distinct from their parent material $(82,83)$. Carbon nanotubes are hollow graphite tubes that can be visualized as a single sheet of graphite rolled to form a cylinder. Carbon nanotubes are comprised of either a single layer (e.g., SWCNT) or multiple layers of individual SWCNTs stacked within one another (e.g., MWCNT), and are manufactured either by electrical arc discharge, laser ablation, or chemical vapor deposition processes $(84,85)$.

The type of carbon nanoparticle (i.e., SWCNT, MWCNT, fullerene), method of processing (i.e., refined or unrefined), presence of residual transition metal catalysts, and functionality 
of different reactive groups are a few of the parameters researchers have tested in cultured cells to better understand which physicochemical characteristics influence toxicity (86-89). SWCNTs, for example, appear to have greater toxic effects on cultured human fibroblasts than MWCNT, active carbon, carbon black, and graphite carbon. In addition, acid treatment (a method of carbon nanotube refinement and removal of residual metal catalysts) of SWCNT produced more toxicity than its unrefined counterpart (89). These findings are supported by other studies that show that acid treatment and subsequent functionalization of SWCNT or fullerenes influence the extent of toxicity on human lung-tumor cell lines and primary immune cells (86-88). The addition of carbonyl-, carboxyl, or hydroxyl groups on the surface of carbon nanotubes induces cell death in lung tumor cells (87).

Functionalization of SWCNTs with water-soluble functional groups appears to influence cellular specific uptake and tolerance by primary immune cells, whereas nonfunctionalized carbon nanotubes induce oxidative stress and apoptosis in a variety of cell systems (90-95).

While clear toxicological differences between carbon nanoparticles functionalized with different chemical moieties have been observed with in vitro cell systems, these same responses are not always seen when administering the same material in vivo. The different toxicity responses of in vitro versus in vivo studies has been specifically observed with functionalized fullerenes administered to different human cell lines (dermal fibroblasts, lung epithelial cells, astrocytes) compared to pulmonary responses of rats administered the same material by intratracheal instillation $(88,96)$. As for in vivo studies conducted on carbon nanotubes, most investigators report inflammation, progressive fibrosis, and granulomas in rodents exposed to carbon nanotubes via intratracheal installation or pharyngeal aspiration. More specifically, as a result of these exposures, acute dose-dependent changes in alveolar wall thickness, immune cell recruitment, and indicators of cellular damage and oxidative stress (measured by levels of inflammatory cells, cytokines, and protein in bronchoalveolar lavage) were observed (97-101). Carbon nanotubes also produce pulmonary function deficits, impairment of bacterial clearance, aortic plaques, and atherosclerotic lesions (99, 102-104).

In an attempt to understand how different physical and chemical parameters contribute to toxicological effects, researchers have evaluated the impact of the method of carbon nanotube production, as well as the influence of milling carbon nanotubes or altering the content and type of metal catalyst on the toxicity in animals $(98,105,106)$. Results suggest that all of the various formulations of carbon nanotubes produce pulmonary lesions (97). A relatively recent published study shows that these effects can be exacerbated by feeding animals a vitamin E-deficient diet, and thereby reducing the antioxidant capacity (glutathione, ascorbate, a-tocopheral) of the lungs while enhancing acute inflammation and fibrotic responses (101).

A few inhalation studies of SWCNTs and MWCNTs using a variety of aerosol delivery systems have recently been published in an attempt to address whether the pulmonary effects of CNTs can be attributed to the method of administration (e.g., pharyngeal aspiration or intratracheal instillation) or the toxicity of the particle itself (107-115). Based on these recent studies, there appears to be a difference in the pattern and extent of pathology across the different types of nanomaterials (SWCNT versus MWCNT), as well as 
approaches for delivery to the respiratory tract (aspiration versus inhalation). MWCNTs delivered by intratracheal instillation or pharyngeal aspiration produces inflammation and fibrosis biochemically and histologically at delivered doses up to $5 \mathrm{mg}$ per rat $(98,116)$, whereas inhalation of aerosolized MWCNTs produces mixed results. For example, no pulmonary lesions were observed following exposure to $100 \mathrm{mg} / \mathrm{m}^{3}$ MWCNTs for $6 \mathrm{hr}$ (109) or $5 \mathrm{mg} / \mathrm{m}^{3}$ MWCNTs for 14 days (108). In fact, in one study, inflammatory responses in the spleen were more sensitive to MWCNT exposures than that observed in the lungs (108). In mice exposed by inhalation to $0.3,1$ or $5 \mathrm{mg} / \mathrm{m}^{3}$ MWCNTs for 7 or 14 days (followed for 7 and 14 days post-exposure), alveolar macrophages in bronchoalveolar lavage and in lung tissue sections contained black particles, but without elevations of white blood cell counts in bronchoalveolar lavage or oxidant stress markers or pathology in the lungs. Changes in immunosuppression markers (e.g., T-cell antibody and proliferative response) and cytokine gene expression of IL-10 and $\mathrm{NAD}(\mathrm{P}) \mathrm{H}$ oxidoreductase, however, were observed in the spleen (108).

In contrast to the negative pathological changes in the above noted studies, other researchers have reported thickening of alveolar walls following exposure to $32 \mathrm{mg} / \mathrm{m}^{3}$ MWCNTs for 15 days (107), lung injury and fibrosis under conditions of pre-existing allergic inflammation following exposure to $100 \mathrm{mg} / \mathrm{m}^{3}$ MWCNTs for $6 \mathrm{hr}$ (109), inflammation and granuloma formation following exposure to 0.5 or $2.5 \mathrm{mg} / \mathrm{m}^{3}$ MWCNTs for 90 days or 0.4 $\mathrm{mg} / \mathrm{m}^{3}$ MWCNTs for 13 weeks $(113,114)$, and subpleural fibrosis and mononuclear cell aggregates following a single $6 \mathrm{hr}$ exposure to $30 \mathrm{mg} / \mathrm{m}^{3}$ MWCNTs (115). To evaluate the effects of inhaled carbon nanotubes, researchers have used a variety of systems, such as a nebulizer, jet mill and powder generator, to aerosolize these carbon-based nanomaterials with median mass aerodynamic diameters (less than $2 \mu \mathrm{m}$ ) within the respirable size range.

In comparison, studies of SWCNTs have reported pulmonary inflammation, interstitial fibrosis, and granulomas following exposure by instillation, pharyngeal aspiration, and inhalation $(97-101,110,117)$. In two studies published by researchers at NIOSH, it has been suggested that administration of dispersed SWCNTs, either by aspiration or inhalation, increase collagen and alveolar wall thickness compared to less dispersed forms of SWCNTs delivered by aspiration $(110,117)$. It has been proposed that SWCNTs elicit these responses by generation of ROS mediated through the presence of residual iron catalysts decorated on the surface of the SWCNTs as well as through release of inflammatory mediators. Although it has been shown that MWCNTs are clearly recognized by alveolar macrophages (108, 109), it has been suggested that evasion of SWCNTs from macrophage phagocytosis might contribute to their facilitated translocation to the interstitium, where the production of collagen is stimulated. Whether macrophage clearance and transepithelial migration, or differences in physicochemistry, can explain the dissimilar pathological patterns in the respiratory tract between MWCNTs and SWCNTs will require further investigation.

Because of the elongated and fibrous nature of carbon nanotubes, some researchers have suggested analogies between these engineered nanoparticles and asbestos. In fact, two studies have compared peritoneal responses of MWCNTs to asbestos following intraperitoneal injection. In one study, inflammatory and granuloma responses in the peritoneal cavity were assessed following an intraperitoneal injection ( $50 \mu \mathrm{g} /$ mouse $)$ of 
MWCNTs or amosite asbestos (long fibers of $10-20+\mu \mathrm{m}$ length or short fibers of $<5 \mu \mathrm{m}$ length) or nanoparticle carbon black (118). It was found that the granulomatous inflammation was greatest for long MWCNTs and amosite formulations as compared those containing mostly short MWCNTs or amosite fibers. While the response observed with long MWCNTs and amosite fibers were similar, the study did not address whether the inflammatory or granulomatous changes would go on to develop mesotheliomas (118). Although highly criticized for its dosing regimen and animal model selection, Takagi et al. (2008) reported mesotheliomas in p53 heterozygous mice following single $3 \mathrm{mg}$ intraperitoneal injections of MWCNTs or crocidolite fibers but not in mice injected with fullerenes (119). In contrast, a two-year bioassay showed no mesotheliomas as a result of single intraperitoneal injections of MWCNTs (with and without structural defects) in mice, whereas significant incidence rates of mesothelioma tumors were observed with intraperitoneal injections of crocidolite (120). Despite the findings in these three studies, further research is clearly needed to evaluate whether any pathological changes in the appropriate animal model can lead to tumors following acute exposure to CNTs via relevant routes of administration (e.g., inhalation) $(118,121,122)$.

\section{Role of Oxidative Stress}

Similar to incidental ambient nanoparticles derived from anthropogenic sources, engineered nanoparticles can produce ROS and oxidative stress through intrinsic physicochemical properties of the nanoparticle, as well as through nanoparticle-cellular interactions with immune and epithelial cells in the lungs. There are a number of different proposed mechanisms by which engineered nanoparticles produce ROS $(28,31)$. First, electron-hole pairs though UV activation could participate in electron donor or capture interactions that generate superoxide or hydroxyl radicals. Second, semiconductor properties could lead to electron jumping from the conduction band to oxygen to generate superoxide. Third, dissolution of the nanoparticle to release metal ions can catalyze ROS generation and, lastly, transition metals on the nanoparticle surface can generate superoxide radicals via Fenton chemistry $(28,31)$. Also, similar to ambient nanosized particles, engineered nanoparticles can produce oxidant injury via nanoparticle-cellular interactions and ROS derived from inflammatory processes and mitochondrial dysfunction.

Given some of the physicochemical similarities (i.e., presence of transition metals, high aspect ratio, potential biopersistence) to other high aspect ratio particles (e.g., asbestos), researchers have sought to understand how the role oxidative stress integrates with some of the health effects seen in the lung following exposure to CNTs. Studies have generally focused on oxidative responses from the presence of residual transition metal catalysts associated with the production of SWCNTs and MWCNTs and/or from phagocytic cells as a result of phagolysosomal activation. When comparing as-produced SWCNTs (containing iron) to purified SWCNTs, where the iron is removed through acid treatment, it has been shown that iron-rich SWCNTs are more effective in stimulating hydroxyl radicals in zymosan-stimulated RAW 264.7 macrophages and increasing intracellular ROS and decreasing mitochondrial membrane potential in rat macrophages and human lung cells than purified SWCNTs lacking iron $(16,123,124)$. While several studies have shown that the presence of transition metals (e.g., iron) is important in determining the redox-dependent 
responses of macrophages, CNTs have other characteristics that make them unique from other toxicants, such as asbestos. Specifically, it has been shown that CNTs may have the ability to quench and scavenge free radicals, which has been proposed to be related to the presence of structure defects and associated with genotoxic and inflammatory potential (16, $105,125)$.

With the massive oxidizing potential of phagolysosomes, it is likely that oxidative modification of phagocytized CNTs may occur. Myeloperoxidase (MPO), a potent oxidant enzyme source in neurtrophils, has been shown to biodegrade SWCNTs in an acellular system $(16,126)$. Treatment of biodegradation products of SWCNTs with MPO failed to induce pulmonary inflammatory responses in mice after pharyngeal aspiration $(16,126)$. It was also observed that the clearance of SWCNTs from MPO-deficient mice was markedly reduced compared to wild-type animals $(15,16)$. Other carbon-based nanoparticles have been shown to undergo similar MPO-catalyzed modifications and degradation $(16,127)$. It has been proposed that hypochlorite and MPO reactive intermediates are possible pathways in which the oxidative biodegradation process occurs $(15,16,127,128)$. Certainly the biodegradation of SWCNTs has tremendous implications for biopersistence and potential long-term health effects from prolonged exposures.

Recent work by Donaldson and colleagues has shown that CNTs are generally durable materials but may undergo biological modification $(16,129)$. Testing the durability of four types of CNTs in simulated biological fluid demonstrated that durable CNTs with short or tightly bundled aggregates with no long isolated fibers were less inflammogenic than the longer CNT counterparts $(16,129)$. Other studies have shown that biodegradation leads to physical and/or chemical modifications. SWCNTs with carboxylated surfaces in artificial phagolysosomal fluid can reduce the length of SWCNTs, as well as result in accumulation of carbonaceous debris. These biodegradation processes certainly have implications for the hazardous potential of these materials.

It has been suggested that CNTs may induce ROS through NADPH oxidase-dependent pathways. In NADPH oxidase-deficient mice, SWCNT exposure resulted in an accumulation of neutrophils, production of pro-inflammatory cytokines, decreases in antiinflammatory and pro-fibrotic cytokines, and less collagen deposition as compared to wildtype control mice $(16,110)$. Similarly, deficiency in antioxidant molecules resulted in increased sensitivity to the inflammatory effects of SWCNTs. Lower levels of antioxidants in vitamin E-deficient mice were associated with greater acute inflammation and enhanced pro-fibrotic responses (increase in TGF- $\beta$ and collagen deposition) following exposure to SWCNTs $(16,101)$. In summary, the research thus far suggests there are multiple factors (e.g., CNT chemistry, biodegradation and antioxidant capacity/susceptibility) that can influence oxidative stress following exposure to CNTs and further research is needed to understand which variables impact or are associated with any progression of pulmonary disease. 


\section{NANOTHERAPEUTICS AGAINST OXIDATIVE INJURY}

One aspect of toxicity testing of nanoparticles that is worth noting is that cellular toxicity may actually be a desired outcome and intended use of the nanoparticle, particularly if the target is tumor cells. While research in the area of biocompatible carbon nanotube design is still in its infancy, investigators are functionalizing these nanoparticles to have sufficient biocompatibility, functionality, distribution, retention, and specificity in hope that these nanomaterials can be utilized as carriers of biologic and therapeutic molecules $(84,85)$. Ways in which researchers are manipulating the chemistry of carbon nanotubes for pharmaceutical applications include entrapment of active components within the CNT matrix or bundle, functional attachment of the compound on the exterior walls of the CNT and use of CNT channels as nanocatheters $(84,85)$. These approaches, as well as the dispersive agents used to solubilize the CNTs, can have dramatic effects on the clearance and retention of these nanomaterials $(130,131)$.

Researchers are investigating ways in which nanomaterials can be used to target and mitigate or augment endogenous oxidative stress as potential preventative or treatment modalities for disease. One example, is the potential use of nanomaterials to transport metal chelating agents to pathological sites of significant and abnormal metal accumulation within Alzheimer disease patients (132). Transition metal accumulations in Alzheimer disease brains are thought to have an important role in local oxidative reactions and pathological lesions. Metal-chelating agents with the assistance of nanocarriers that can cross the bloodbrain barrier (regardless of their size and hydrophilicity), selectively bind, remove and "redox-silence" transition metals provide promising potential for therapeutic intervention (132). Engineered nanomaterials may be also act as targeted enhancers of oxidative stress for tumor or cancer therapy. Chemical modification of fullerenes can target mitochondria inducing significant mitochondrial ROS formation leading to enhanced apoptosis and necrosis (26). Alternatively, "minor" mitochrondrial ROS formation is thought to "precondition" by preventing propagation of mitochrondrial ROS during oxidative insults, thus providing potential opportunities for the development of nano antioxidants (26). Thus, ROS targeted strategies for either enhancement or prevention of oxidative stress may offer useful approaches for therapeutic interventions in the treatment of cancer, mitochrondial disease, and aging disease such as in the case of Alzheimer's disease.

\section{CONCLUSION}

In summary, emerging research on engineered nanoparticles (i.e., CNTs), as well as on nanoparticles in ambient air particle pollution have demonstrated that oxidative stress can be an important mechanism for toxicity and potential health effects in the lung. There are number of pathways and intrinsic/extrinsic nanoparticle properties by which an imbalance in the prooxidant and antioxidant equilibrium can result in an oxidative stress state. The presence of transition metal catalysts, organic compounds which can undergo redox cycling, as well as other surface chemistries (functionalization) can influence the intrinsic potential of nanoparticles to produce oxidative species. Additionally, the biodegradability and biopersistence of nanoparticles are likely to influence the nanoparticle-cellular interactions which in turn may have direct effects on the cellular or organelle oxidative status (e.g., 
mitochondrial cell signaling) or indirect effects through inflammatory processes (e.g., oxidative burst and phagolysosome activation) and enzymatic detoxification pathways. Certainly, genetic or epigenetic phenotypes that influence the prooxidant or antioxidant capacity (e.g., polymorphisms in GST) of an individual may have implications for the susceptibility of oxidative stress and potential health effects following exposure to engineered or incidental nanoparticles. Past experience with particles or fibers like asbestos and silica would suggest that characteristics such as surface reactivity, morphology, and biopersistence that influence the generation of reactive oxygen species, persistent inflammation, impaired macrophage clearance, and fibrotic lesions would likely be important parameters for driving the hazards of carbon nanotubes. Additional research in the area of engineered nanomaterials will likely continue to focus on the role of transition metals in the generation of ROS, length and morphology in influencing particle fate and transport, and surface chemistry (functional groups, dangling bonds) in directing cellular responses.

\section{ACKNOWLEDGEMENTS}

The authors acknowledge the following sources of support which provided the basis for our literature review: NIEHS U01 ES02027, RC1 ES018232, P01 ES00628, NCRR RR00169, NIOSH OHO7550, EPA RD-832414, California Tobacco-Related Disease Research Program18XT-0154, California Air Resources Board Contracts 06-331 and 09-330.

\section{REFERENCES}

1. Alivisatos P. Colloidal quantum dots. From scaling laws to biological applications. Pure \& Appl Chem. 2000; 72:3-9.

2. Drexler, KE. Nanosystems: Molecular, machinery, manufacturing, and composition. New York, NY: Wiley-Interscience Publication; 1992.

3. Hu JT, Odom TW, Lieber CM. Chemistry and physics in one dimension: Synthesis and properties of nanowires and nanotubes. Accounts Chem Res. 1999; 32:435-445.

4. Lieber C. Nanoscale science and technology: Building a big future from small things. MRS Bulletin. 2003; 28:486-491.

5. Navrotsky A. Thermochemistry of nanomaterials. Nanoparticles Environ. 2001; 44:73-103.

6. Smalley R. Wires of wonder. Technol Rev. 2001; 104:86-91.

7. West JL, Halas NJ. Engineered nanomaterials for biophotonics applications: Improving sensing, imaging, and therapeutics. Ann Rev Biomed Eng. 2003; 5:285-292. [PubMed: 14527314]

8. ASTM International. Standard terminology relating to nanotechnology. West Conshohocken, PA: American Society for Testing and Materials (ASTM International; 2006.

9. Churg, AM.; Green, FHY. Occupational lung disease. In: Churg, AM.; Myers, JL.; Tazelaar, HD.; Wright, JL., editors. Thurlbeck's pathology of the lung. New York: Thieme Medical Publishers, Inc; 2005.

10. U.S. Environmental Protection Agency. Air quality criteria for particulate matter. Washington, DC: U.S. Environmental Protection Agency (US EPA), EPA 600/P-99/002aF-bF; 2004.

11. U.S. Environmental Protection Agency. Provisional assessment of recent studies on particulate matter. Washington, DC: U.S. Environmental Protection Agency (US EPA), EPA/600/R-06/063; 2006.

12. Ayres JG, Borm P, Cassee FR, Castranova V, Donaldson K, et al. Evaluating the toxicity of airborne particulate matter and nanoparticles by measuring oxidative stress potential--a workshop report and consensus statement. Inhal Toxicol. 2008; 20:75-99. [PubMed: 18236225]

13. Moller P, Jacobsen NR, Folkmann JK, Danielsen PH, Mikkelsen L, et al. Role of oxidative damage in toxicity of particulates. Free Radic Res. 2010; 44:1-46. [PubMed: 19886744] 
14. Knaapen AM, Borm PJ, Albrecht C, Schins RP. Inhaled particles and lung cancer. Part A: Mechanisms. Int J Cancer. 2004; 109:799-809. [PubMed: 15027112]

15. Shvedova AA, Kapralov AA, Feng WH, Kisin ER, Murray AR, et al. Impaired clearance and enhanced pulmonary inflammatory/fibrotic response to carbon nanotubes in myeloperoxidasedeficient mice. PLoS One. 2012; 7:e30923. [PubMed: 22479306]

16. Shvedova AA, Pietroiusti A, Fadeel B, Kagan VE. Mechanisms of carbon nanotube-induced toxicity: focus on oxidative stress. Toxicol Appl Pharmacol. 2012; 261:121-133. [PubMed: 22513272]

17. Kovacic P, Somanathan R. Biomechanisms of nanoparticles (toxicants, antioxidants and therapeutics): electron transfer and reactive oxygen species. J Nanosci Nanotechnol. 2010; 10:7919-7930. [PubMed: 21121279]

18. Li JJ, Muralikrishnan S, Ng CT, Yung LY, Bay BH. Nanoparticle-induced pulmonary toxicity. Exp Biol Med (Maywood). 2010; 235:1025-1033. [PubMed: 20719818]

19. Zhou YM, Zhong CY, Kennedy IM, Leppert VJ, Pinkerton KE. Oxidative stress and NFkappaB activation in the lungs of rats: a synergistic interaction between soot and iron particles. Toxicol Appl Pharmacol. 2003; 190:157-169. [PubMed: 12878045]

20. Forman HJ, Torres M. Reactive oxygen species and cell signaling: Respiratory burst in macrophage signaling. Am J Respir Crit Care Med. 2002; 166:S4-S8. [PubMed: 12471082]

21. Raad H, Paclet MH, Boussetta T, Kroviarski Y, Morel F, et al. Regulation of phagocyte NADPH oxidase activity: Phosphorylation of gp91(phox)/NOX2 by protein kinase $\mathrm{C}$ enhances its diaphorase activity and binding to Rac2, p67(phox), and p47(phox). FASEB J. 2009; 23:10111022. [PubMed: 19028840]

22. Lambeth JD, Kawahara T, Diebold B. Regulation of Nox and Duox enzymatic activity and expression. Free Radic Biol Med. 2007; 43:319-331. [PubMed: 17602947]

23. Boueiz A, Hassoun PM. Regulation of endothelial barrier function by reactive oxygen and nitrogen species. Microvasc Res. 2009; 77:26-34. [PubMed: 19041330]

24. Duchen MR. Mitochondria and calcium: from cell signalling to cell death. J Physiol. 2000; 1 (529 Pt):57-68. [PubMed: 11080251]

25. Duchen MR. Roles of mitochondria in health and disease. Diabetes. 2004; 1(53 Suppl):S96-S102. [PubMed: 14749273]

26. Jou MJ. Pathophysiological and pharmacological implications of mitochondria-targeted reactive oxygen species generation in astrocytes. Adv Drug Deliv Rev. 2008; 60:1512-1526. [PubMed: 18692534]

27. Marano F, Hussain S, Rodrigues-Lima F, Baeza-Squiban A, Boland S. Nanoparticles: molecular targets and cell signalling. Arch Toxicol. 2011; 85:733-741. [PubMed: 20502881]

28. Nel A, Xia T, Madler L, Li N. Toxic potential of materials at the nanolevel. Science. 2006; 311:622-627. [PubMed: 16456071]

29. Xia T, Kovochich M, Brant J, Hotze M, Sempf J, et al. Comparison of the abilities of ambient and manufactured nanoparticles to induce cellular toxicity according to an oxidative stress paradigm. Nano Lett. 2006; 6:1794-1807. [PubMed: 16895376]

30. Li N, Hao M, Phalen RF, Hinds WC, Nel AE. Particulate air pollutants and asthma: a paradigm for the role of oxidative stress in PM-induced adverse health effects. Clin Immunol. 2003; 109:250 265. [PubMed: 14697739]

31. Li N, Xia T, Nel AE. The role of oxidative stress in ambient particulate matter-induced lung diseases and its implications in the toxicity of engineered nanoparticles. Free Radic Biol Med. 2008; 44:1689-1699. [PubMed: 18313407]

32. Xiao GG, Wang M, Li N, Loo JA, Nel AE. Use of proteomics to demonstrate a hierarchical oxidative stress response to diesel exhaust particle chemicals in a macrophage cell line. $\mathrm{J}$ Biol Chem. 2003; 278:50781-50790. [PubMed: 14522998]

33. Chan K, Kan YW. Nrf2 is essential for protection against acute pulmonary injury in mice. Proc Natl Acad Sci U S A. 1999; 96:12731-12736. [PubMed: 10535991]

34. Cho HY, Jedlicka AE, Reddy SP, Kensler TW, Yamamoto M, et al. Role of NRF2 in protection against hyperoxic lung injury in mice. Am J Respir Cell Mol Biol. 2002; 26:175-182. [PubMed: 11804867] 
35. Cho HY, Reddy SP, Kleeberger SR. Nrf2 defends the lung from oxidative stress. Antioxid Redox Signal. 2006; 8:76-87. [PubMed: 16487040]

36. Li N, Nel AE. Role of the Nrf2-mediated signaling pathway as a negative regulator of inflammation: implications for the impact of particulate pollutants on asthma. Antioxid Redox Signal. 2006; 8:88-98. [PubMed: 16487041]

37. Hiura TS, Li N, Kaplan R, Horwitz M, Seagrave JC, Nel AE. The role of a mitochondrial pathway in the induction of apoptosis by chemicals extracted from diesel exhaust particles. J Immunol. 2000; 165:2703-2711. [PubMed: 10946301]

38. Aust AE, Cook PM, Dodson RF. Morphological and chemical mechanisms of elongated mineral particle toxicities. J Toxicol Environ Health B Crit Rev. 2011; 14:40-75. [PubMed: 21534085]

39. Fubini B, Hubbard A. Reactive oxygen species (ROS) and reactive nitrogen species (RNS) generation by silica in inflammation and fibrosis. Free Radic Biol Med. 2003; 34:1507-1516. [PubMed: 12788471]

40. Gulumian M, Borm PJ, Vallyathan V, Castranova V, Donaldson K, et al. Mechanistically identified suitable biomarkers of exposure, effect, and susceptibility for silicosis and coal-worker's pneumoconiosis: a comprehensive review. J Toxicol Environ Health B Crit Rev. 2006; 9:357-395. [PubMed: 16990219]

41. Mossman BT, Lippmann M, Hesterberg TW, Kelsey KT, Barchowsky A, Bonner JC. Pulmonary endpoints (lung carcinomas and asbestosis) following inhalation exposure to asbestos. J Toxicol Environ Health B Crit Rev. 2011; 14:76-121. [PubMed: 21534086]

42. Brown DM, Stone V, Findlay P, MacNee W, Donaldson K. Increased inflammation and intracellular calcium caused by ultrafine carbon black is independent of transition metals or other soluble components. Occup Environ Med. 2000; 57:685-691. [PubMed: 10984341]

43. Brown DM, Wilson MR, MacNee W, Stone V, Donaldson K. Size-dependent proinflammatory effects of ultrafine polystyrene particles: a role for surface area and oxidative stress in the enhanced activity of ultrafines. Toxicol Appl Pharmacol. 2001; 175:191-199. [PubMed: 11559017]

44. Dick CA, Brown DM, Donaldson K, Stone V. The role of free radicals in the toxic and inflammatory effects of four different ultrafine particle types. Inhal Toxicol. 2003; 15:39-52. [PubMed: 12476359]

45. Ferin J, Oberdorster G, Penney DP. Pulmonary retention of ultrafine and fine particles in rats. Am J Respir Cell Mol Biol. 1992; 6:535-542. [PubMed: 1581076]

46. Stoeger T, Reinhard C, Takenaka S, Schroeppel A, Karg E, et al. Instillation of six different ultrafine carbon particles indicates a surface area threshold dose for acute lung inflammation in mice. Environ Health Perspect. 2006; 114:328-333. [PubMed: 16507453]

47. Stone V, Johnston H, Clift MJ. Air pollution, ultrafine and nanoparticle toxicology: cellular and molecular interactions. IEEE Trans Nanobioscience. 2007; 6:331-340. [PubMed: 18217626]

48. Stone V, Shaw J, Brown DM, Macnee W, Faux SP, Donaldson K. The role of oxidative stress in the prolonged inhibitory effect of ultrafine carbon black on epithelial cell function. Toxicol In Vitro. 1998; 12:649-659. [PubMed: 20654455]

49. Dockery DW, Pope CA 3rd, Xu X, Spengler JD, Ware JH, et al. An association between air pollution and mortality in six U.S. cities. N Engl J Med. 1993; 329:1753-1759. [PubMed: 8179653]

50. Dockery DW. Epidemiologic evidence of cardiovascular effects of particulate air pollution. Environ Health Perspect. 2001; 109(Suppl 4):483-486. [PubMed: 11544151]

51. Pope CA 3rd. Epidemiology of fine particulate air pollution and human health: biologic mechanisms and who's at risk? Environ Health Perspect. 2000; 4(108 Suppl):713-723. [PubMed: 10931790]

52. Samet JM, Dominici F, Curriero FC, Coursac I, Zeger SL. Fine particulate air pollution and mortality in 20 U.S. cities, 1987-1994. N Engl J Med. 2000; 343:1742-1749. [PubMed: 11114312]

53. Pinkerton KE, Green FH, Saiki C, Vallyathan V, Plopper CG, et al. Distribution of particulate matter and tissue remodeling in the human lung. Environ Health Perspect. 2000; 108:1063-1069. [PubMed: 11102298] 
54. Brook JR, Dann TF. The relationship among TSP, PM10, PM2.5, and inorganic constituents of atmospheric particulate matter at multiple Canadian locations. J Air Waste Manage Assoc. 1997; 47:2-19.

55. Churg A, Brauer M, Vedal S, Stevens B. Ambient mineral particles in small airways of the normal human lung. J Environ Med. 1999; 1:39-45.

56. Churg A, Brauer M. Human lung parenchyma retains PM2.5. Am J Respir Crit Care Med. 1997; 155:2109-2111. [PubMed: 9196123]

57. Churg A, Brauer M, del Carmen Avila-Casado M, Fortoul TI, Wright JL. Chronic exposure to high levels of particulate air pollution and small airway remodeling. Environ Health Perspect. 2003; 111:714-718. [PubMed: 12727599]

58. Sint T, Donohue JF, Ghio AJ. Ambient air pollution particles and the acute exacerbation of chronic obstructive pulmonary disease. Inhal Toxicol. 2008; 20:25-29. [PubMed: 18236218]

59. Smith KR, Kim S, Recendez JJ, Teague SV, Menache MG, et al. Airborne particles of the california central valley alter the lungs of healthy adult rats. Environ Health Perspect. 2003; 111:902-908. discussion A408-9. [PubMed: 12782490]

60. Churg A, Wright JL. Bronchiolitis caused by occupational and ambient atmospheric particles. Semin Respir Crit Care Med. 2003; 24:577-584. [PubMed: 16088574]

61. Dai J, Xie C, Vincent R, Churg A. Air pollution particles produce airway wall remodeling in rat tracheal explants. Am J Respir Cell Mol Biol. 2003; 29:352-358. [PubMed: 12649123]

62. Kooter I, Pennings J, Opperhuizen A, Cassee F. Gene expression pattern in spontaneously hypertensive rats exposed to urban particulate matter (EHC-93). Inhal Toxicol. 2005; 17:53-65. [PubMed: 15764483]

63. Araujo JA, Barajas B, Kleinman M, Wang X, Bennett BJ, et al. Ambient particulate pollutants in the ultrafine range promote early atherosclerosis and systemic oxidative stress. Circ Res. 2008; 102:589-596. [PubMed: 18202315]

64. Cho AK, Sioutas C, Miguel AH, Kumagi Y, Schmitz DA, et al. Redox activity of airborn particulate matter at different sites in the Los Angeles Basin. Environ Res. 2005; 99:40-47. [PubMed: 16053926]

65. Deguillaume L, Leriche M, Desboeufs K, Mailhot G, George C, Chaumerliac N. Transition metals in atmospheric liquid phases: Sources, reactivity, and sensitive parameters. Chem Res. 2005; 105:3388-3431.

66. Vidrio E, Jung H, Anastasio C. Generation of hydroxyl radicals from dissolved transition metals in surrogate lung fluid solutions. Atmos Environ. 2008; 42:4369-4379.

67. Carter JD, Ghio AJ, Samet JM, Devlin RB. Cytokine production by human airway epithelial cells after exposure to an air pollution particle is metal-dependent. Toxicol Appl Pharmacol. 1997; 146:180-188. [PubMed: 9344885]

68. Rouse RL, Murphy G, Boudreaux MJ, Paulsen DB, Penn AL. Soot nanoparticles promote biotransformation, oxidative stress, and inflammation in murine lungs. Am J Respir Cell Mol Biol. 2008; 39:198-207. [PubMed: 18367723]

69. Squadrito GL, Cueto R, Dellinger B, Pryor WA. Quinoid redox cycling as a mechanism for sustained free radical generation by inhaled airborne particulate matter. Free Radical Biology and Medicine. 2001; 31:1132-1138. [PubMed: 11677046]

70. Ades EW, Candal FJ, Swerlick RA, George VG, Summers S, et al. HMEC-1: establishment of an immortalized human microvascular endothelial cell line. J Invest Dermatol. 1992; 99:683-690. [PubMed: 1361507]

71. Baulig A, Sourdeval M, Meyer M, Marano F, Baeza-Squiban A. Biological effects of atmospheric particles on human bronchial epithelial cells. Comparison with diesel exhaust particles. Toxicol In Vitro. 2003; 17:567-573. [PubMed: 14599446]

72. Li N, Sioutas C, Cho A, Schmitz D, Misra C, et al. Ultrafine particulate pollutants induce oxidative stress and mitochondrial damage. Environ. Health Perspect. 2003; 111:455-460. [PubMed: 12676598]

73. Li N, Wang M, Oberley TD, Sempf JM, Nel AE. Comparison of the pro-oxidative and proinflammatory effects of organic diesel exhaust particle chemicals in bronchial epithelial cells and macrophages. J Immunol. 2002; 169:4531-4541. [PubMed: 12370390] 
74. Kumagai Y, Arimoto T, Shinyashiki M, Shimojo N, Nakai Y, et al. Generation of reactive oxygen species during interaction of diesel exhaust particle components with NADPH-cytochrome P450 reductase and involvement of the bioactivation in the DNA damage. Free Radic Biol Med. 1997; 22:479-487. [PubMed: 8981040]

75. Monks TJ, Hanzlik RP, Cohen GM, Ross D, Graham DG. Quinone chemistry and toxicity. Toxicol Appl Pharmacol. 1992; 112:2-16. [PubMed: 1733045]

76. Nel AE, Diaz-Sanchez D, Ng D, Hiura T, Saxon A. Enhancement of allergic inflammation by the interaction between diesel exhaust particles and the immune system. J Allergy Clin Immunol. 1998; 102:539-554. [PubMed: 9802360]

77. Lim HB, Ichinose T, Miyabara Y, Takano H, Kumagai Y, et al. Involvement of superoxide and nitric oxide on airway inflammation and hyperresponsiveness induced by diesel exhaust particles in mice. Free Radic Biol Med. 1998; 25:635-644. [PubMed: 9801062]

78. Sagai M, Saito H, Ichinose T, Kodama M, Mori Y. Biological effects of diesel exhaust particles. I. In vitro production of superoxide and in vivo toxicity in mouse. Free Radic Biol Med. 1993; 14:37-47. [PubMed: 8384149]

79. Takano H, Lim HB, Miyabara Y, Ichinose T, Yoshikawa T, Sagai M. Manipulation of the Larginine-nitric oxide pathway in airway inflammation induced by diesel exhaust particles in mice. Toxicology. 1999; 139:19-26. [PubMed: 10614685]

80. Whitekus MJ, Li N, Zhang M, Wang M, Horwitz MA, et al. Thiol antioxidants inhibit the adjuvant effects of aerosolized diesel exhaust particles in a murine model for ovalbumin sensitization. $\mathrm{J}$ Immunol. 2002; 168:2560-2567. [PubMed: 11859152]

81. Gilliland FD, Li YF, Gong H Jr, Diaz-Sanchez D. Glutathione s-transferases M1 and P1 prevent aggravation of allergic responses by secondhand smoke. Am J Respir Crit Care Med. 2006; 174:1335-1341. [PubMed: 17023730]

82. Donaldson K, Aitken R, Tran L, Stone V, Duffin R, et al. Carbon nanotubes: a review of their properties in relation to pulmonary toxicology and workplace safety. Toxicol Sci. 2006; 92:5-22. [PubMed: 16484287]

83. Lam CW, James JT, McCluskey R, Arepalli S, Hunter RL. A review of carbon nanotube toxicity and assessment of potential occupational and environmental health risks. Crit Rev Toxicol. 2006; 36:189-217. [PubMed: 16686422]

84. Foldvari M, Bagonluri M. Carbon nanotubes as functional excipients for nanomedicines: I. Pharmaceutical properties. Nanomed. 2008; 4:173-182.

85. Foldvari M, Bagonluri M. Carbon nanotubes as functional excipients for nanomedicines: II. Drug delivery and biocompatibility issues. Nanomed. 2008; 4:183-200.

86. Dumortier H, Lacotte S, Pastorin G, Marega R, Wu W, et al. Functionalized carbon nanotubes are non-cytotoxic and preserve the functionality of primary immune cells. Nano Lett. 2006; 6:15221528. [PubMed: 16834443]

87. Magrez A, Kasas S, Salicio V, Pasquier N, Seo JW, et al. Cellular toxicity of carbon-based nanomaterials. Nano Lett. 2006; 6:1121-1125. [PubMed: 16771565]

88. Sayes CM, Marchione AA, Reed KL, Warheit DB. Comparative pulmonary toxicity assessments of $\mathrm{C} 60$ water suspensions in rats: Few differences in fullerene toxicity in vivo in contrast to in vitro profiles. Nano Lett. 2007; 7:2399-2406. [PubMed: 17630811]

89. Tian F, Cui D, Schwarz H, Estrada GG, Kobayashi H. Cytotoxicity of single-wall carbon nanotubes on human fibroblasts. Toxicol In Vitro. 2006; 20:1202-1212. [PubMed: 16697548]

90. Bottini M, Bruckner S, Nika K, Bottini N, Bellucci S, et al. Multi-walled carbon nanotubes induce T lymphocyte apoptosis. Toxicol Lett. 2006; 160:121-126. [PubMed: 16125885]

91. Cui D. Effect of single wall carbon nanotubes on human HEK293 cells. Toxicol Lett. 2005; 155:73-85. [PubMed: 15585362]

92. Ding L, Stilwell J, Zhang T, Elboudwarej O, Jiang H, et al. Molecular characterization of the cytotoxic mechanism of multiwall carbon nanotubes and nano-onions on human skin fibroblast. Nano Lett. 2005; 5:2448-2464. [PubMed: 16351195]

93. Jia G, Wang H, Yan L, Wang X, Pei R, et al. Cytotoxicity of carbon nanomaterials: Single-wall nanotube, multi-wall nanotube, and fullerene. Environ Sci Technol. 2005; 39:1378-1383.

[PubMed: 15787380] 
94. Manna SK, Sarkar S, Barr J, Wise K, Barrera EV, et al. Single-walled carbon nanotube induces oxidative stress and activates nuclear transcription factor-kappaB in human keratinocytes. Nano Lett. 2005; 5:1676-1684. [PubMed: 16159204]

95. Monteiro-Riviere NA, Nemanich RJ, Inman AO, Wang YY, Riviere JE. Multi-walled carbon nanotube interactions with human epidermal keratinocytes. Toxicol Lett. 2005; 155:377-384. [PubMed: 15649621]

96. Sayes CM, Fortner JD, Guo W, Lyon D, Boyd AM, et al. The differential cytotoxicity of watersoluble fullerenes. Nano Lett. 2004; 4:1881-1887.

97. Lam CW, James JT, McCluskey R, Hunter RL. Pulmonary toxicity of single-wall carbon nanotubes in mice 7 and 90 days after intratracheal instillation. Toxicol Sci. 2004; 77:126-134. [PubMed: 14514958]

98. Muller J, Huaux F, Moreau N, Misson P, Heilier JF, et al. Respiratory toxicity of multi-wall carbon nanotubes. Toxicol Appl Pharmacol. 2005; 207:221-231. [PubMed: 16129115]

99. Shvedova AA, Kisin ER, Mercer R, Murray AR, Johnson VJ, et al. Unusual inflammatory and fibrogenic pulmonary responses to single-walled carbon nanotubes in mice. Am J Physiol Lung Cell Mol Physiol. 2005; 289:L698-L708. [PubMed: 15951334]

100. Warheit DB, Laurence BR, Reed KL, Roach DH, Reynolds GA, Webb TR. Comparative pulmonary toxicity assessment of single-wall carbon nanotubes in rats. Toxicol Sci. 2004; 77:117-125. [PubMed: 14514968]

101. Shvedova AA, Kisin ER, Murray AR, Gorelik O, Arepalli S, et al. Vitamin E deficiency enhances pulmonary inflammatory response and oxidative stress induced by single-walled carbon nanotubes in C57BL/6 mice. Toxicol Appl Pharmacol. 2007; 221:339-348. [PubMed: 17482224]

102. Li ZJ. Pulmonary exposure to carbon nanotubes induces vascular toxicity. Toxicologist. 2005; 84:213.

103. Li ZJ. Relationship between pulmonary exposure to multiple doses of single wall carbon nanotubes and atherosclerosis in ApoE -l- mouse model. Toxicologist. 2006; 90:318.

104. Li Z, Hulderman T, Salmen R, Chapman R, Leonard SS, et al. Cardiovascular effects of pulmonary exposure to single-wall carbon nanotubes. Environ Health Perspect. 2007; 115:377382. [PubMed: 17431486]

105. Muller J, Huaux F, Fonseca A, Nagy JB, Moreau N, et al. Structural defects play a major role in the acute lung toxicity of multiwall carbon nanotubes: Toxicological aspects. Chem Res Toxicol. 2008; 21:1698-1705. [PubMed: 18636756]

106. Tong H, McGee JK, Saxena RK, Kodavanti UP, Devlin RB, Gilmour MI. Influence of acid functionalization on the cardiopulmonary toxicity of carbon nanotubes and carbon black particles in mice. Toxicol Appl Pharmacol. 2009; 239:224-232. [PubMed: 19481103]

107. Li JG, Li WX, Xu JY, Cai XQ, Liu RL, et al. Comparative study of pathological lesions induced by multiwalled carbon nanotubes in lungs of mice by intratracheal instillation and inhalation. Environ Toxicol. 2007; 22:415-421. [PubMed: 17607736]

108. Mitchell LA, Gao J, Wal RV, Gigliotti A, Burchiel SW, McDonald JD. Pulmonary and systemic immune response to inhaled multiwalled carbon nanotubes. Toxicol Sci. 2007; 100:203-214. [PubMed: 17660506]

109. Ryman-Rasmussen JP, Tewksbury EW, Moss OR, Cesta MF, Wong BA, Bonner JC. Inhaled multiwalled carbon nanotubes potentiate airway fibrosis in murine allergic asthma. Am J Respir Cell Mol Biol. 2009; 40:349-358. [PubMed: 18787175]

110. Shvedova AA, Kisin E, Murray AR, Johnson VJ, Gorelik O, et al. Inhalation vs. aspiration of single-walled carbon nanotubes in C57BL/6 mice: inflammation, fibrosis, oxidative stress, and mutagenesis. Am J Physiol Lung Cell Mol Physiol. 2008; 295:L552-L565. [PubMed: 18658273]

111. Ellinger-Ziegelbauer H, Pauluhn J. Pulmonary toxicity of multi-walled carbon nanotubes (Baytubes) relative to alpha-quartz following a single $6 \mathrm{~h}$ inhalation exposure of rats and a 3 months post-exposure period. Toxicology. 2009; 266:16-29. [PubMed: 19836432]

112. Li JG, Li QN, Xu JY, Cai XQ, Liu RL, et al. The pulmonary toxicity of multi-wall carbon nanotubes in mice 30 and 60 days after inhalation exposure. J Nanosci Nanotechnol. 2009; 9:1384-1387. [PubMed: 19441530] 
113. Ma-Hock L, Treumann S, Strauss V, Brill S, Luizi F, et al. Inhalation toxicity of multiwall carbon nanotubes in rats exposed for 3 months. Toxicol Sci. 2009; 112:468-481. [PubMed: 19584127]

114. Pauluhn J. Subchronic 13-week inhalation exposure of rats to multiwalled carbon nanotubes: toxic effects are determined by density of agglomerate structures, not fibrillar structures. Toxicol Sci. 2010; 113:226-242. [PubMed: 19822600]

115. Ryman-Rasmussen J, Cesta M, Brody A, Shipley-Phillips J, Everitt J, et al. Inhaled carbon nanotubes reach the subpleural tissue in mice. Nat Nanotechnol. 2009; 4:747-751. [PubMed: 19893520]

116. Han SG, Andrews R, Gairola CG, Bhalla DK. Acute pulmonary effects of combined exposure to carbon nanotubes and ozone in mice. Inhal Toxicol. 2008; 20:391-398. [PubMed: 18302047]

117. Mercer RR, Scabilloni J, Wang L, Kisin E, Murray AR, et al. Alteration of deposition pattern and pulmonary response as a result of improved dispersion of aspirated single-walled carbon nanotubes in a mouse model. Am J Physiol Lung Cell Mol Physiol. 2008; 294:L87-L97. [PubMed: 18024722]

118. Poland CA, Duffin R, Kinloch I, Maynard A, Wallace WA, et al. Carbon nanotubes introduced into the abdominal cavity of mice show asbestos-like pathogenicity in a pilot study. Nat Nanotechnol. 2008; 3:423-428. [PubMed: 18654567]

119. Takagi A, Hirose A, Nishimura T, Fukumori N, Ogata A, et al. Induction of mesothelioma in p53+/- mouse by intraperitoneal application of multi-wall carbon nanotube. J Toxicol Sci. 2008; 33:105-116. [PubMed: 18303189]

120. Muller J, Delos M, Panin N, Rabolli V, Huaux F, Lison D. Absence of carcinogenic response to multi-wall carbon nanotubes in a 2-year bioassay in the peritoneal cavity of the rat. Toxicol Sci. 2009; 110:442-448. [PubMed: 19429663]

121. Donaldson K, Stone V, Seaton A, Tran L, Aitken R, Poland C. Re: Induction of mesothelioma in p53+/- mouse by intraperitoneal application of multi-wall carbon nanotube. J Toxicol Sci. 2008; 33:385. author reply 86-8. [PubMed: 18670173]

122. Ichihara G, Castranova V, Tanioka A, Miyazawa K. Re: Induction of mesothelioma in p53+/mouse by intraperitoneal application of multi-wall carbon nanotube. J Toxicol Sci. 2008; 33:381382. author reply 82-4. [PubMed: 18670171]

123. Kagan VE, Tyurina YY, Tyurin VA, Konduru NV, Potapovich AI, et al. Direct and indirect effects of single walled carbon nanotubes on RAW 264.7 macrophages: role of iron. Toxicol Lett. 2006; 165:88-100. [PubMed: 16527436]

124. Pulskamp K, Diabate S, Krug HF. Carbon nanotubes show no sign of acute toxicity but induce intracellular reactive oxygen species in dependence on contaminants. Toxicol Lett. 2007; 168:58-74. [PubMed: 17141434]

125. Fenoglio I, Greco G, Tomatis M, Muller J, Raymundo-Pinero E, et al. Structural defects play a major role in the acute lung toxicity of multiwall carbon nanotubes: Physicochemical aspects. Chem Res Toxicol. 2008; 21:1690-1697. [PubMed: 18636755]

126. Kagan VE, Konduru NV, Feng W, Allen BL, Conroy J, et al. Carbon nanotubes degraded by neutrophil myeloperoxidase induce less pulmonary inflammation. Nat Nanotechnol. 2010; 5:354-359. [PubMed: 20364135]

127. Bianco A, Kostarelos K, Prato M. Making carbon nanotubes biocompatible and biodegradable. Chem Commun (Camb). 2011; 47:10182-10188. [PubMed: 21776531]

128. Vlasova II, Sokolov AV, Chekanov AV, Kostevich VA, Vasil'ev VB. [Myeloperoxidase-induced biodegradation of single-walled carbon nanotubes is mediated by hypochlorite]. Bioorg Khim. 2011; 37:510-521. [PubMed: 22096994]

129. Osmond-McLeod MJ, Poland CA, Murphy F, Waddington L, Morris H, et al. Durability and inflammogenic impact of carbon nanotubes compared with asbestos fibres. Part Fibre Toxicol. 2011; 8:15. [PubMed: 21569450]

130. Schipper ML, Nakayama-Ratchford N, Davis CR, Kam NW, Chu P, et al. A pilot toxicology study of single-walled carbon nanotubes in a small sample of mice. Nat Nanotechnol. 2008; 3:216-221. [PubMed: 18654506] 
131. Singh R, Pantarotto D, Lacerda L, Pastorin G, Klumpp C, et al. Tissue biodistribution and blood clearance rates of intravenously administered carbon nanotube radiotracers. Proc Natl Acad Sci U S A. 2006; 103:3357-3362. [PubMed: 16492781]

132. Bonda DJ, Liu G, Men P, Perry G, Smith MA, Zhu X. Nanoparticle delivery of transition-metal chelators to the brain: Oxidative stress will never see it coming! CNS Neurol Disord Drug Targets. 2012; 11:81-85. [PubMed: 22229318] 


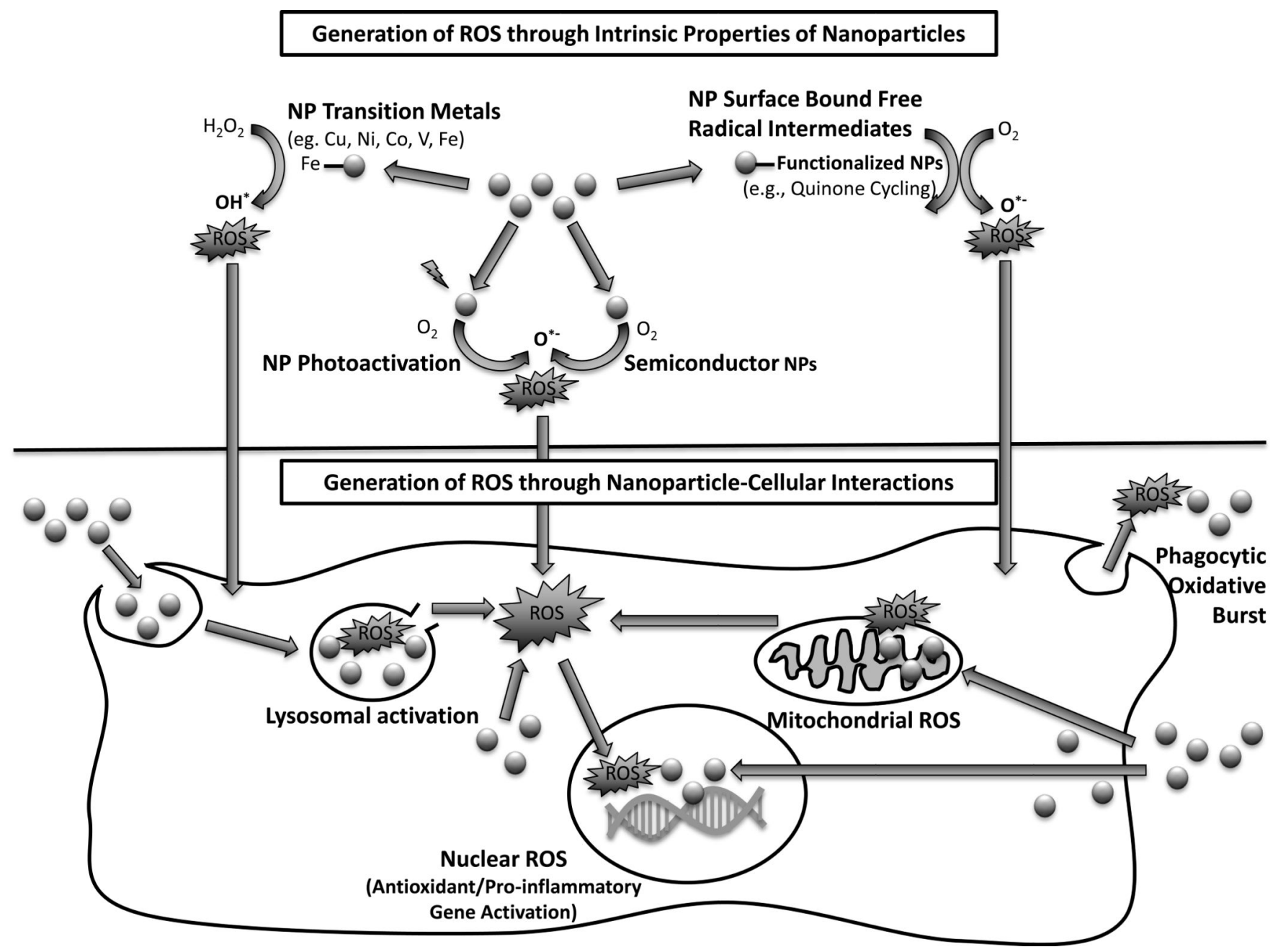

Figure 1.

Nanoparticles exhibit intrinsic oxidant-generating properties. Nanoparticles may contain transition metals due to particle engineering or as a by-product capable of generating ROS through Fenton-like chemical reactions. Free radical intermediates present on reactive nanoparticle surfaces and redox active groups (e.g., quinones) on nanoparticles are capable of redox cycling producing superoxide or hydroxyl radicals. Nanoparticles with semiconductor properties are capable of generating superoxide via electron jumping from the conduction band to oxygen and photocatalytic capable nanoparticles facilitate the creation of electron-hole pairs generating ROS such as superoxide or hydroxyl radicals. Also, nanoparticles generate and contribute to oxidative stress through direct and indirect cellular interactions. Nanoparticle interaction and damage to internal cellular structures such as lysosomes, mitochondria and the nucleus, can lead to cellular damage and oxidative stress. Through direct gene interaction with nanoparticles or nuclear oxidative stress, activation of signaling pathways for antioxidant or pro-oxidant responses may be upregulated. Additionally, nanoparticles may indirectly interact with cells to alter ROS production and emission through modified cellular phagocytic activity and oxidative burst. 


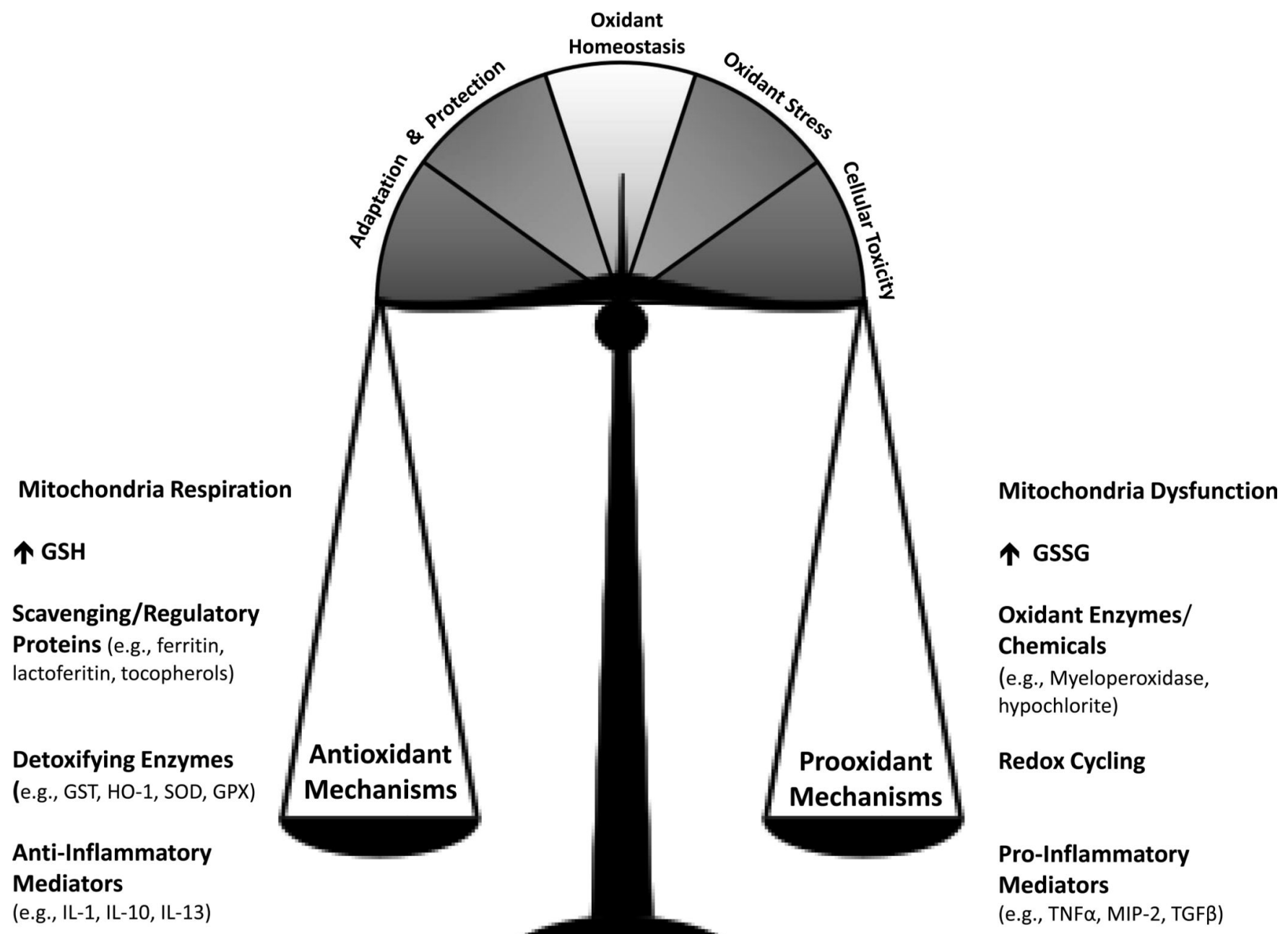

Figure 2.

Oxidative stress reflects the imbalance between the generation of ROS and the biochemical mechanisms to detoxify and repair resulting damage of reactive intermediates. Antioxidant defense, inflammation, and toxicity follow a continuum from adaption and compensation of oxidant stresses to an in equilibrium whereby the protective antioxidant mechanisms breakdown or are overwhelmed. 

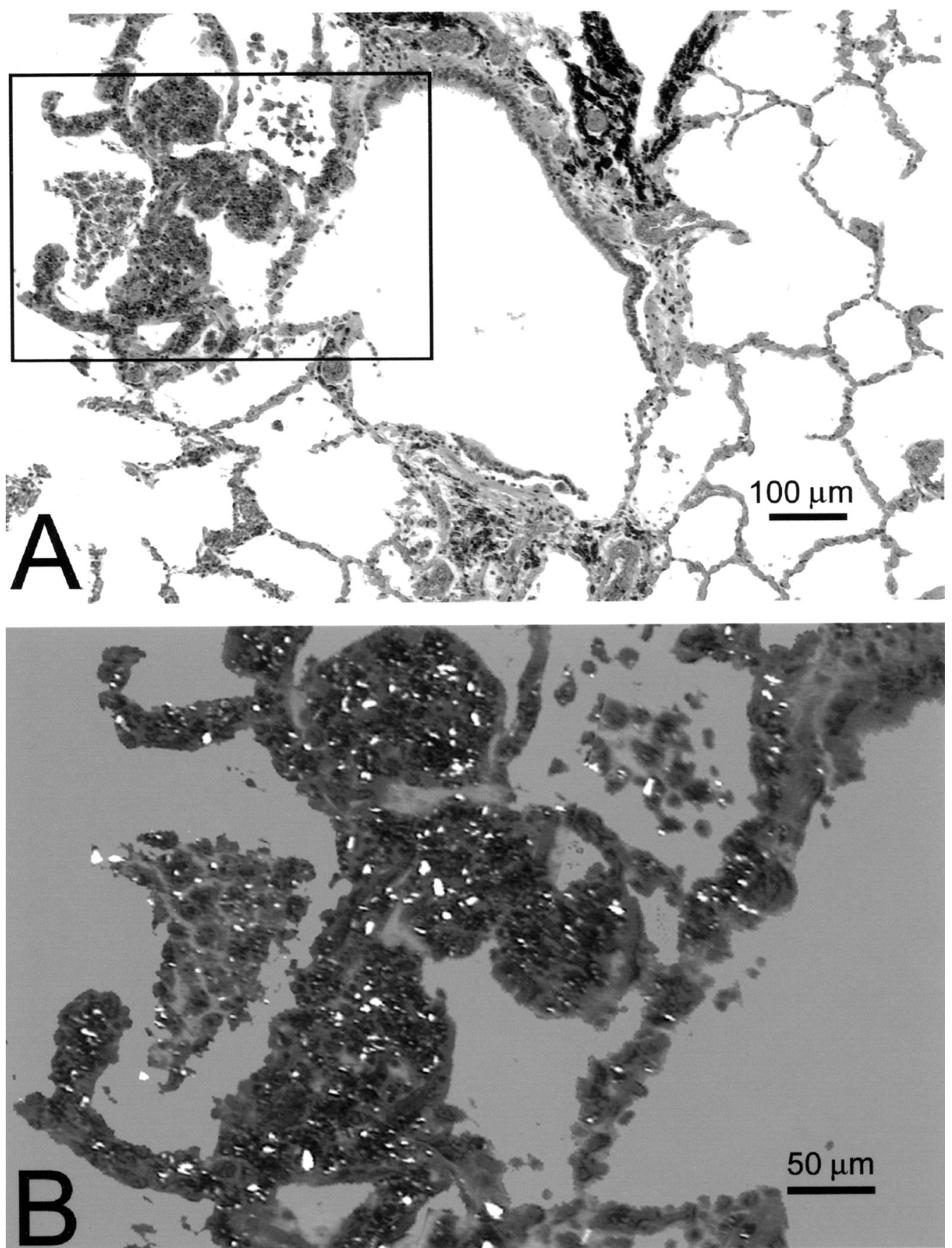

Figure 3.

Bright field (A) and polarized field (B) images of a first generation respiratory bronchiole from a human lung of a 32 year old farm laborer. The inset in panel A and shown in panel B contains numerous polarized particles within intraluminal macrophages as well as within the walls of the respiratory bronchiole and adjacent alveoli. (Reproduced by permission, Environmental Health Perspectives) 

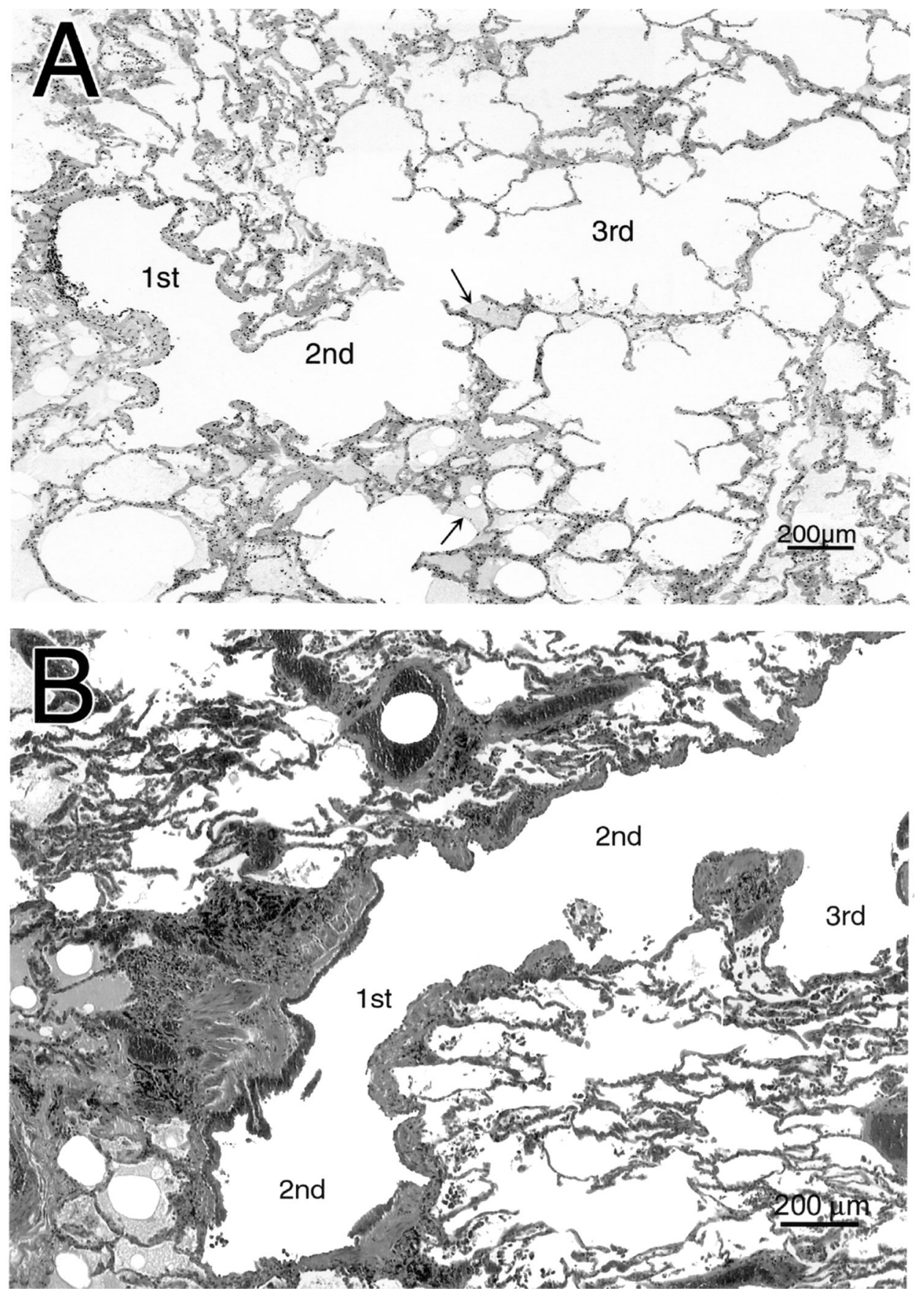

Figure 4.

Light micrographs of contiguous first-, second- and third-generation respiratory bronchioles from the human lung showing the normal structural anatomy (A) and marked alterations (B) due to increased amounts of interstitial collagen, smooth muscle and visible pigment. These structural changes are most dramatic in the first generation respiratory bronchiole with a progressive decrease in more distal generations. (Reproduced by permission, Environmental Health Perspectives) 